
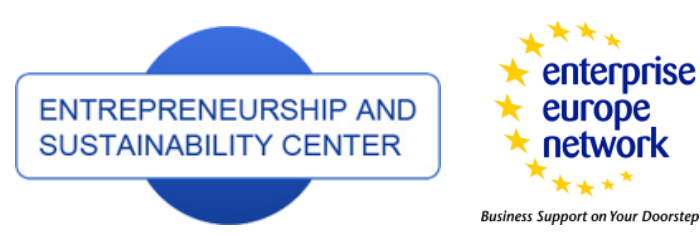

http://doi.org/10.9770/jesi.2017.5.2(5)

Publisher

http://jssidoi.org/esc/home

\title{
SUSTAINABLE MARKETING COMMUNICATION STRATEGIES OF RUSSIAN COMPANIES UNDER THE IMPORT SUBSTITUTION POLICY
}

\author{
Veronika Yu. Chernova1, Alexander M. Zobov², Vasily S. Starostin ${ }^{3}$, Galina V. Butkovskaya ${ }^{4}$ \\ ${ }^{1,2}$ Peoples' Friendship University of Russia \\ 6, Miklukho-Maklaya Str., Moscow, 117198, Russian Federation \\ ${ }^{3,4}$ State University of Management \\ 99, Ryazanskiy prospect st., Moscow, 109542, Russian Federation \\ E-mails: ${ }^{1}$ veronika_urievna@mail.ru; ${ }^{2}$ a_zobov@mail.ru$;{ }^{3}$ vs_starostin@guu.ru; ${ }^{4}$ gvb@mail.ru
}

Received 15 July 2017; accepted 26 October 2017; published 29 December 2017

\begin{abstract}
The sanction standoff between Russia and the West opened up new opportunities for Russian food manufacturers. A new import substitution policy declared by the government restricted the access of the leading foreign countries to the market and unlocked a potential for internal development. Russian producers spotted new niches in the food market. There exist numerous obstacles to assimilating new market prospects: organizational (logistics, infrastructure, etc.), investment, legal, economic, etc. The paper underlines that the problem of enhancing the effectiveness of food companies' marketing policy in the context of import substitution is among the most formidable challenges. The article generalizes the problems of implementing the marketing policy of Russian enterprises. It reviews the core findings of the research studies on exploring consumers' attitude towards Russian and foreign-made food products. The author formulates recommendations about executing sustainable marketing communication strategies of Russian companies under import substitution.
\end{abstract}

Keywords: marketing communications, import substitution, food products, consumer goods

Reference to this paper should be made as follows: Chernova, V. Y.; Zobov, A. M.; Starostin, V. S.; Butkovskaya, G. V. 2017. Sustainable marketing communication strategies of Russian companies under the import substitution policy, Entrepreneurship and Sustainability Issues 5(2): 223-230. http://doi.org/10.9770/jesi.2017.5.2(5)

JEL Classifications: Q13, Q18, M30

\section{Introduction}

The recent global geopolitical crisis and subsequent events have caused a large number of dramatic changes in the economic policy employed by national governments. For example, in response to the restriction of Russian companies' access to Western financial resources, technologies and other economic goods associated with specific economic sectors, the Russian government adopted a set of measures aimed primarily at import substitution or a gradual substitution of imported products with domestically produced goods. 
The idea of import substitution is not new to Russia. However, it was not until 2013-2014 that the country started actively implementing this concept. The ban on importation of agricultural products from several countries to the territory of the Russian Federation led to both positive and negative consequences for the Russian economy (Edict, 2014). For many years, foreign-made food products have been dominating the Russian food market, especially during the period from 2000 to 2013, and it could not but influence the current behavioral patterns and food preferences of Russian consumers. A number of foodstuffs items were perceived by Russian manufacturers as purely foreign products with consistent quality. The situation was aggravated by the fact that Russian consumers displayed a comparative attitude towards particular types of foreign-made and domestic food products. Undoubtedly, under such conditions, in order to guarantee substitution of imported food products for domestically produced foodstuffs, it is necessary to resolve problems with product perception and require from Russian manufacturers to mount appropriate marketing efforts, including communication.

Thus, in modern conditions there emerged a problem of adapting marketing communication strategies of Russian producers. The scholarly significance of the present study lies in systematization of Russian consumers' incentives to choose food products of domestic production. The practical importance of the paper resides in designing a set of recommendations that can be taken into account when formulating sustainable marketing communication strategies for ensuring risk sustainability of companies' activity (Guseva and Kuzmin, 2016; Kuzmin, 2017).

The purpose of the study is to identify the special features of transformation of the motives behind behavior and choice of food products by Russian consumers in the context of implementing the import substitution policy. To achieve this purpose, we plan to perform the following research tasks: (1) to analyze the extent to which the problem of forming a marketing strategy under import substitution is rectified; (2) to suggest the author's interpretation of the findings of the research studies on the Russian consumer's behavior in the food market; and (3) to provide a set of recommendations to boost the effectiveness of sustainable marketing communication strategies of Russian food manufacturers in the context of the import substitution policy.

\section{Literature review}

Undoubtedly, implementation of the import substitution policy, in addition to the issues of marketing communication support, encounters a range of other equally important problems. This is the reason why the majority of the Russian scientific research are devoted to resolving the issues of legal, financial, infrastructuretechnical and other support for implementation of the import substitution policy.

Nevertheless, there emerge more and more research studies on marketing problems associated with the introduction of the import substitution policy and its specific aspects. In particular, we can mention the following. Vinogradova (Vinogradova, 2017) argues that in today's conditions the expansion of agricultural marketing is impossible without transforming marketing activity of concrete economic entities. In their work, Grishchenko and Sumina (Grishchenko and Sumina, 2015) discuss the issues of strategic planning of Russian companies in the context of the import substitution policy. Some scientists believe that autarky measures (which incorporate the import substitution policy) pose a threat to economic security and damage the welfare of the population while reducing the number of possible alternatives to consumer choice (Kuzmin, 2015; Kuzmin, 2016).

The research study by Marchenko (Marchenko, 2016) specifies the methodological base of import substitution in the sectoral markets, identifies the main factors encouraging the development of the sectoral market and formulates a set of measures to increase the effectiveness of the import substitution policy in the sectoral market. Having studied the theoretical base of marketing and marketing communication, Mechikova (Mechikova, 2017) suggests a set of measures to improve the activities of Russian companies in this sphere. Moskalev (Moskalev, 2017) looks at the strategy of differentiation of market entities' product brands as the major competition tool in the conditions of the import substitution policy. Yudina and Pirogova (Yudina and Pirogova, 2017) consider 
individual techniques for developing and executing advertising campaigns under the import substitution policy. However, the publications mentioned above pay little attention to the issues of formation of effective and sustainable marketing communication strategies in the context of the import substitution policy, but deal with only certain aspects of this problem.

In addition to the aforementioned publications, it is worth mentioning the research studies exploring preferences of Russian consumers in the food market. Amongst such works are investigations conducted by the Institute of Public Opinion "Anketolog" (Anketolog, 2015), the Public Opinion Fund "Fond Obshchestvennoe Mnenie" (FOM, 2015), as well as publications by Bondarenko, Babich and Chertyanina (Bondarenko, Babich and Chertyanina, 2016), Guziy and Ondreyovichova (Guziy and Ondreyovichova, 2015), Marakova, Sharafutdinova and Krishtafovich (Marakova, Sharafutdinova and Krishtafovich, 2016), et al.

\section{Research results}

In the course of implementing import substitution measures, Russian companies have managed to accumulate sufficient experience in performing marketing communication strategies. To evaluate this experience, the author carried out a research study of various enterprises engaged in production or selling of food products. The fundamental hypothesis of the research is that in the new environment Russian manufacturers do not take into account the ongoing transformations in the structure of the needs of the national consumer. The survey was conducted from March to May 2017. During the study, 164 respondents from marketing departments of different companies were interviewed. In the course of the research, the author used a structured interview. The table 1 below shows characteristics of the survey participants according to main parameters.

Table 1. Sampling of the research

\begin{tabular}{|l|c|c|}
\hline \multicolumn{1}{|c|}{ Parameter } & Number of respondents & $\%$ of respondents \\
\hline Geographical spread of participants, including: & 164 & 100,0 \\
\hline Moscow & 56 & 34,1 \\
\hline Saint Petersburg & 48 & 29,3 \\
\hline Krasnodar & 14 & 8,5 \\
\hline Rostov-on-Don & 13 & 7,9 \\
\hline Saratov & 9 & 5,5 \\
\hline Kazan & 9 & 5,5 \\
\hline Nizhniy Novgorod & 8 & 4,9 \\
\hline Pskov & 7 & 4,3 \\
\hline Sectoral specialization, including: & 164 & 100,0 \\
\hline meat products & 69 & 42,1 \\
\hline dairy products & 58 & 35,4 \\
\hline fruits and vegetables & 37 & 22,5 \\
\hline Type of organization, including: & 164 & 100,0 \\
\hline manufacturing & 34 & 20,7 \\
\hline trade and manufacturing & 56 & 34,1 \\
\hline trade & 74 & 45,2 \\
\hline
\end{tabular}

We analyzed the findings of the survey and arrived at the following conclusions:

1 ) in most cases (65\% of respondents), food companies do not increase the budget for communication support of their products;

2) the majority of the companies under consideration (78\% of respondents) do not have clear long-term goals formulated in the form of a strategic marketing communication plan regarding their future prospects; 
ENTREPRENEURSHIP AND SUSTAINABILITY ISSUES

ISSN 2345-0282 (online) http://jssidoi.org/jesi/

2017 Volume 5 Number 2 (December)

http://doi.org/10.9770/jesi.2017.5.2(5)

3) marketing communication strategies are executed without in-depth studies at regional level (this is especially true in regard to small and medium-sized companies);

4) in most cases (56\%), when formulating their marketing communication messages, Russian companies do not pay attention to large-scale studies and consumer motives.

\section{Discussion}

\subsection{Review of representative research}

In our view, it is worth analyzing the main results of representative studies that characterize Russian consumers and their attitude towards food products in the context of import substitution. As mentioned above, in recent years there have appeared a large number of research that can shed light on the key parameters of Russian target audience in the food markets.

These studies demonstrate that most Russians are in favour of the ban on importing certain goods from the EU countries. For instance, according to one of the surveys, $46 \%$ of 1149 respondents indicated that retaliatory sanctions introduced recently can become a solid support to domestic food manufacturers and regarded these measures as positive (Guziy and Ondreyovichova, 2015).

When analyzing behavioural aspects of Russian consumers, it is important to touch upon the problem of their comparative attitude towards particular types of foreign-made and domestic food products. For example, the research undertaken by the Public Opinion Fund "Fond Obshchestvennoe Mnenie" (FOM, 2015) produced quite interesting results when comparing consumers' attitude towards the quality of food products of domestic and foreign production (Fig. 1). The study was held among Russian citizens above 18 years, 1500 respondents in total; in 104 populated localities situated in 53 subjects of the Russian Federation.

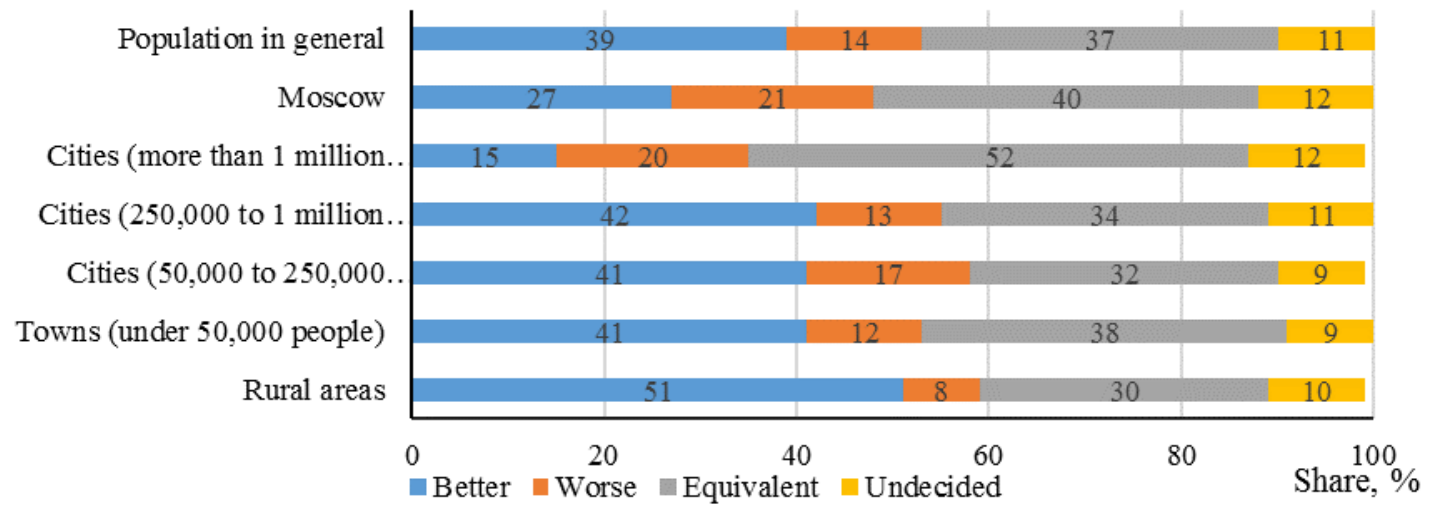

Figure 1. Attitude of Russian consumers towards the quality of food products of domestic and foreign production

Source: Domestically produced food products vs. imported food products (FOM, 2015)

As we can see, the Russian population, in general, is favorably disposed towards domestically produced goods. However, from the territorial aspect, the results vary significantly. The most critical view of Russian produced goods is characteristic of large cities with population over 1 million people - only $15 \%$ of respondents said that domestic products were of a better quality than imported goods, and only $20 \%$ expressed the dissenting opinion. The situation is radically different in rural areas, where $51 \%$ of respondents believed that the quality of Russian 
ENTREPRENEURSHIP AND SUSTAINABILITY ISSUES

ISSN 2345-0282 (online) http://jssidoi.org/jesi/

2017 Volume 5 Number 2 (December)

http://doi.org/10.9770/jesi.2017.5.2(5)

food products was higher if compared with foreign-made foodstuffs. The given data allow us to draw the following practical conclusions:

1) in human settlements with population less than 1 million people, Russian consumers have more trust in domestic food products than in urban areas with population over 1 million inhabitants. In this regard, Russian food manufacturers, especially of the federal level, can differentiate their communication policy (in terms of forming a budget for communication, depending on the intensity of using communication media) according to consumers' attitude;

2) a more detailed differentiation is required in the sphere of utilizing marketing communication tools in large urban areas and human settlements with population less than 1 million people.

At the same time, according to scientific research, there is a decrease in Russian consumers' confidence in food products of domestic production (Fig. 2).

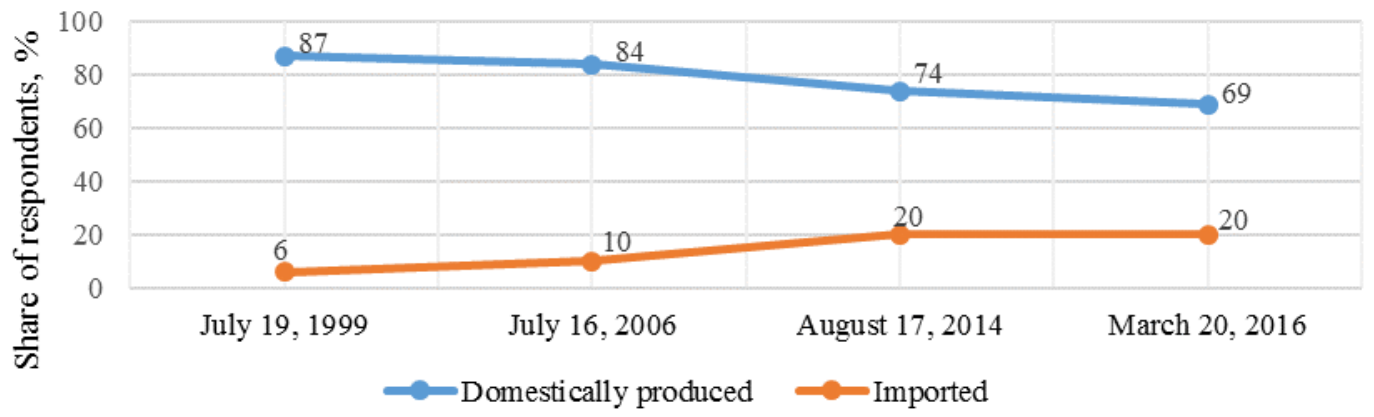

Figure 2. Dynamics of Russian consumers' attitude towards domestically produced and imported food products in 1999-2016

Source: Domestically produced food products vs. imported food products (FOM, 2015)

As we can notice, despite the fact that Russian consumers still prefer domestically manufactured food products, their indifference to the country of origin of foodstuffs is becoming more obvious. The Russian food market, in terms of the number of brands presented, is still at the nascent stage. A gradually decreasing interest of Russian consumers in domestic food products signifies the absence of strong brands that could be serious competitors to foreign analogues. The increase in indifference of consumers is also attributed to their poor loyalty. Hence, investing in brand creation, despite its high cost, is among strategically important tasks of mapping out sustainable marketing communication strategies for manufacturers seeking long-term profitability.

When implementing a marketing communication strategy, it is of practical interest to examine Russian consumers' motives for purchasing domestically produced food products. Incentives can become the basis for creating communication messages. According to the research conducted by the Public Opinion Fund (FOM, 2015), such incentives embrace the following: better quality of Russian food products (18\% of respondents); organic food products without GMOs or harmful food additives $(17 \%)$; greater reliability, confidence in a product $(16 \%)$, patriotic motives (13\%); better palatability (5\%); more attractive prices (5\% of respondents).

Other research underline similar motivations for choosing products of domestic production. For example, according to the survey performed by the Institute of Public Opinion "Anketolog" (Anketolog, 2015), Russian consumers identified the following incentives for buying domestically manufactured goods: adequate prices (75\% of respondents), the use of organic raw materials (71\%); acceptable quality of production (50\%); product reliability (30\%); durability (25\%); a wide product range (14\%); high functionality of products (10\%); product appearance $(5 \%)$; stylish design (3\% of respondents). 
ENTREPRENEURSHIP AND SUSTAINABILITY ISSUES

ISSN 2345-0282 (online) http://jssidoi.org/jesi/

2017 Volume 5 Number 2 (December)

http://doi.org/10.9770/jesi.2017.5.2(5)

The above-listed factors and motivations for purchasing domestic products cannot be used in all market niches in the same way. Without a doubt, every company has to identify the objectives of enhancing the effectiveness of communication strategies, the structure of consumer preferences, motives and factors in purchasing a specific product. While forming a sustainable marketing communication strategy, companies should also take into account the motives behind the purchase of foreign-made products. The recent study (Guziy and Ondreyovichova, 2015) demonstrated that such motives include: confidence in a product (41\% of respondents); higher quality (32\%); information availability (26\%); better brand awareness (23\%); better palatability (14\%); more attractive prices (5\% of respondents). Thus, identifying of consumer preferences, their dynamics and structure becomes one of the determining factors in building effective marketing communication strategies in the context of the import substitution policy.

\subsection{Recommendations}

There are numerous approaches to the formation of marketing communication strategies, but ultimately all of them pursue common communication objectives. Summarizing the results of the present study, we can formulate the following recommendations to improve the effectiveness of marketing communication strategies of Russian manufacturers of food products under the import substitution policy:

(1) The funds channeled by Russian companies into marketing research are insufficient. Under the conditions of import substitution, it is equally important, when constructing sustainable marketing communication strategies, to utilize the results of secondary marketing studies of Russian consumers, as well as the findings of primary marketing research corresponding to the specific goals and tasks of particular companies;

(2) "Patriotic" motivations do not always prevail even under import substitution. This factor can be taken into account in the process of formation of marketing communication strategies, but it should not be viewed as central and basic;

(3) Building sustainable marketing communication strategies requires the territorial factor to be considered. Under modern conditions, it is advisable for Russian food companies, especially those operating in several regional markets or nationwide, to adapt their communication strategies to specific conditions of every local market individually;

(4) Formation of marketing communication strategies of Russian companies is associated with communication strategies of chain retailers. This fact should be taken into consideration in long-term strategic plans.

\section{Conclusion}

In the course of implementing import substitution measures, Russian companies have accumulated extensive experience of executing marketing communication strategies. The findings of the analysis indicate that in most cases (65\% of respondents) food companies do not increase their budget for communication support of products and the majority of organizations (78\% of respondents) do not have clear long-term goals represented in the form of a strategic plan of marketing communications regarding the company's position in the future. All this proves the necessity to gradually alter marketing communication strategies of Russian manufacturers. In this connection, identifying the avenues for boosting the effectiveness and sustainability of marketing communication strategies in the context of import substitution requires taking into account the distinguishing features of consumer behavior. The recent trends allow us to conclude that Russian consumers are increasingly less concerned with the country of origin of food products. Thus, it is of crucial importance to analyze consumer preferences, as well as their dynamics and structure, in order to form effective and sustainable marketing strategies. 
ENTREPRENEURSHIP AND SUSTAINABILITY ISSUES

ISSN 2345-0282 (online) http://jssidoi.org/jesi/

2017 Volume 5 Number 2 (December)

http://doi.org/10.9770/jesi.2017.5.2(5)

\section{References}

Anketolog (the Institute of Public Opinion). 2015. The Real Attitude of Russian consumers to Domestic Manufacturers. Available on the Internet: < https://iom.anketolog.ru/2015/10/20/istinnoe-otnoshenie-rossiyan-k-otechestvennomu-proizvoditelyu >.

Bondarenko, V. A.; Babich, Ya. M.; Chertyanina, Ye. E. 2016. Marketing and Marketing Research in Import Substitution Initiatives of Agricultural Machinery and Agricultural Products, Scientific and Methodological Electronic Journal "Koncept” 17: 945-949. Available on the Internet: 〈http://e-koncept.ru/2016/46364.htm〉.

Edict of the Government of the Russian Federation of August 7, 2014 no. 778 "On measures to implement decrees of the President of the Russian Federation of August 6, 2014 no. 560, of June 24, 2015 no. 320, of June 29, 2016 no. 305, and of June 30, 2017 no. 293 ”. 2014. Rossiyskaya Gazeta 178. August, 8.

Grishchenko, I. A.; Sumina, E. V. 2015. Marketing Strategy of a Company in the Context of the Import Substitution Policy. Proceeding of the $5^{\text {th }}$ International Scientific-Practical Conference "The Study of the Innovation Potential of Society and Formation of Directions for Its Strategic Development”: December 29-30, Kursk, Russia. Kursk: Universitetskaya kniga, 144-148.

Guseva, V. E.; Kuzmin, E. A. 2016. Survival Rate and Lifecycle in Terms of Uncertainty: Review of Companies from Russia and Eastern Europe, Journal of Advanced Research in Law and Economics 7(21): 1754-1766. https://doi.org/10.14505//jarle.v7.7(21).23

Guziy, S.; Ondreyovichova, M. 2015. Analysis of Consumer Preferences in the Russian Food Market, Moscow Economic Journal. Available on the Internet: < http://qje.su/marketing/analiz-predpochtenij-pokupatelej-na-rynke-produktov-pitaniya-rossii/>.

Kuzmin, E. A. 2015. Food Security Modelling, Biosciences Biotechnology Research Asia 12(2): 773-781. http://dx.doi.org/10.13005/bbra/2259

Kuzmin, E. A. 2016. Sustainable Food Security: Floating Balance of Markets, International Journal of Economics and Financial Issues 6(1): 37-44. Available on the Internet: < https://www.econjournals.com/index.php/ijefi/article/viewFile/1575/pdf>

Kuzmin, E. A. 2017. Risk and Uncertainty in Concept of Corporate Lifecycle, Problems and Perspectives in Management 15(1): 107-114. Available on the Internet: 〈http://www.twirpx.com/file/2206835/>

Marakova, A. V.; Sharafutdinova, D. R.; Krishtafovich, V. I. 2016. The Study of Consumer Preferences for Meat Products in the Framework of Import Substitution Products, Fundamental and Applied Research of the Cooperative Sector of Economy 4: 70-78.

Marchenko, Yu. O. 2016. The Role of Import Substitution in the Development of the Russian Pharmaceutical Market. Cand. econ. sci. diss. Moscow, Russia.

Mechikova, M. N. 2017. Marketing Activity of Russian Industrial Enterprises in Terms of Import, Bulletin of the Siberian Institute of Business and Information Technologies 1(21): 45-51.

Moskalev, S. M. 2017. Strategy of Trademarks Differentiation in Strengthening the Competitive Positions of Market Entities. Proceedings of the International Scientific-Practical Conference "Scientific Support for Agricultural Development and Reduction of Technological Risks in the Food Sector”: Vol. 2, St Petersburg, Russia. St Petersburg: SPSAU Publ., 70-73.

FOM (the Public Opinion Fund "Fond Obshchestvennoe Mnenie"). 2015. Domestically Produced Food Products vs. Imported Food Products. Available on the Internet: 〈http://fom.ru/Ekonomika/12587〉.

Vinogradova, T. G. 2017. Activation of Agricultural Marketing in the Conditions of a Significant Change in the Competitive Environment. Proceedings of the International Scientific-Practical Conference "Scientific Support for Agricultural Development and Reduction of Technological Risks in the Food Sector”: Vol. 2, St Petersburg, Russia. St Petersburg: SPSAU Publ., 5-8.

Yudina, E. A.; Pirogova, N. V. 2015. Import-Substituting Advertisements of Food Products: Current State, Agrarian Bulletin of the Urals 6(136): 94-96. 
ENTREPRENEURSHIP AND SUSTAINABILITY ISSUES

ISSN 2345-0282 (online) http://jssidoi.org/jesi/

2017 Volume 5 Number 2 (December)

http://doi.org/10.9770/jesi.2017.5.2(5)

Veronika Yu. CHERNOVA, Associate Professor, Cand. Sci. (Economic), People's Friendships University of Russia, Department of Marketing. Professional interests: world economy, marketing of transnational companies, importsubstitution, product personalization, oneto-one marketing, interactive marketing communications. Recent articles are published in a cooperation with research colleaques in a field of retailer's communication strategies; product personalization, managing data-driven advertising campaigns.

ORCID ID: orcid.org/0000-0001-5951-9091

Alexander M. ZOBOV, Professor, Cand. Sci. (Economic), People's Friendships University of Russia, Head of the Department of Marketing. Professional interests: cooperation with BRICs countries, international marketing strategies, strategic marketing, world economy, marketing of transnational companies, importsubstitution, product personalization, one-to-one marketing, interactive marketing communications. Recent articles are published in a cooperation with research colleaques in a field of retailer's communication strategies; product personalization, managing data-driven advertising campaigns.

ORCID ID: orcid.org/0000-0002-8792-1990

Vasily S. STAROSTIN, Associate Professor, Cand. Sci. (Economic), Head of Advertising and PR Department, Institute of Marketing, State University of Management. Professional interests: product personalization, one-to-one marketing, interactive marketing communications. Recent articles are published in a cooperation with research colleaques in a field of retailer's communication strategies; product personalization, managing data-driven advertising campaigns.

ORCID ID: orcid.org/0000-0003-2243-7345

Galina V. BUTKOVSKAYA, Associate Professor, Cand. Sci. (Economic), Institute of Marketing, State University of Management. Professional interests: marketing strategy, digital marketing, marketing communications. Recent articles are published in a cooperation with research colleaques in a field of practical aspects of applying the model of operational digital marketing; native advertising as a tool of communication campaigns; how digital environment transforms operational marketing.

ORCID ID: orcid.org/0000-0002-2659-4391

Copyright (C) 2017 by author(s) and VsI Entrepreneurship and Sustainability Center This work is licensed under the Creative Commons Attribution International License (CC BY). http://creativecommons.org/licenses/by/4.0/

\section{(c) $\underset{\text { EY }}{ }$ Open Access}

